\title{
PENGARUH METODE EDUKASI CERAMAH DAN DISKUSI TERHADAP PENGETAHUAN KADER KESEHATAN DALAM DETEKSI DINI DEMAM BERDARAH DENGUE
}

\section{Education Method of Lectures and Discussionstoward Health Cadre Ability in Early Detection of Dengue Hemorrhagic Fever}

\author{
Anita Rahmawati* ${ }^{*}$, Siti Markamah ${ }^{1}$ \\ ${ }^{1}$ STIKes Patria Husada Blitar \\ *Koresponden Penulis :anitarahmawati2017@gmail.com
}

\begin{abstract}
Abstrak
Keluhan demam sering terjadi pada banyak penyakit mulai kondisi ringan hingga penyakit yang membutuhkan perawatan segera seperti Deman berdarah dengue (DBD) namun masyarakat sering kurang menyadari sehingga berakibat fatal akhirnya menyebabkan kematian.Tujuan penelitian ini untuk mengetahui pengaruh metode edukasi ceramah dan diskusi terhadap pengetahuan kader kesehatan dalam deteksi dini DBD. Desain penelitian menggunakan pretest postest without control group. Total populasi diambil menjadi sampel yaitu 30 kader kesehatan di desa Suruhwadang kecamatan Kademangan kabupaten Blitar. Pengetahuan kader kesehatan meliputi pemahaman pengertian, mengenali tanda gejala, penyebab, penatalaksanaan, pencegahan, siklus/fase DBD dan tanda sindrom syok dengue yang diukur dengan kuesioner. Analisis data dengan Wilcoxon sign rank test. $53 \%$ kader kesehatan mempunyai pengetahuan baik saat pretest menjadi $83 \%$ saat posttest. Analisa data menunjukkan ada perbedaan pengetahuan kader kesehatan antara pretest dan postest $(\mathrm{p}=0,001)$. Perpaduan metode edukasi ceramah dan diskusi menjadi metode yang tepat karena peserta edukasi tidak hanya pasif mendengarkan edukator tetapi dapat menjadi lebih aktif untuk menyampaikan pendapat, membuat kesimpulan atau memecahkan masalah sesuai materi yang dipelajari. Diharapkan petugas kesehatan dapat meningkatkan pengetahuan kader kesehatan dalam deteksi dini DBD untuk mencegah akibat fatal dari penyakit ini.
\end{abstract}

Kata kunci: Ceramah, Diskusi, DBD, Edukasi, Kader Kesehatan

\begin{abstract}
Fever was a chief complain that frequently occur in some diseases ranging from mild diseases upto that require immediate care such as Dengue Haemorrhagic Fever (DHF), but people were still often didn't yet aware so that there was fatal consequences eventually leading to the death. The purpose of this study was to determine influence of lecture and discussion methods on ability of health cadres in early detection of DHF. Pretest-posttest without control group design was used in this study.Total population was taken from 30 health cadres at Suruhwadang village, Kademangan district, Blitar district. The ability of health cadres include understanding and recognizing of DHF such as definition, sign and symptom, cause, management, prevention, dengue cycle and the sign of dengue syok syndrome measured by a questionnaire. Data was analyzed by Wilcoxon sign rank test. There were about 53\% health cadres that have good ability at pretest became $83 \%$ at posttest. Data analysis showed that there was a distinction in the ability of health cadres between pretest and posttest $(p=0.001)$. Combination of lecture and discussion methodswere the right methods because participants were not only passively listening to educators but could became more active in expressing opinion, making conclusion or solving problem according to the material was being studied. It is be expected that health workers can improve the ability of health cadres in early detection of DHF so thatcan prevent fatal consequences of this disease.
\end{abstract}

Keywords: Lectures, Discussions, DHF, Education, Health Cadre

Submitted : : 16 Mei 2020, Accepted : 7 Juni 2020

Website : jurnal.stikespamenang.ac.di | Email : jurnal.pamenang@gmail.com 


\section{Pendahuluan}

Keluhan demam sering terjadi pada banyak penyakit mulai kondisi ringan hingga penyakit yang membutuhkan perawatan segera. Penyakit-penyakit yang ditandai dengan adanya demam seperti flu, demam thypoid, demam chikungunya, leptospirosis, virus dengue dan berbagai penyakit lainnya. Dari sekian banyak penyakit yang di tandai dengan adanya demam, infeksi virus dengue dapat menyebabkan manifestasi klinis yang beraneka ragam, mulai dari tanpa gejala (asimtomatik), demam ringan yang tidak spesifik (undif-ferentiated illness), demam dengue (DD), atau bentuk yang lebih berat yaitu demam berdarah dengue (DBD), sindrom syok dengue (SSD) sampai kematian (Wowor, 2011).

Demam berdarah dengue (DBD) adalah suatu penyakit disebabkan oleh virus dengue yang ditularkan oleh nyamuk aedes aegypti dan aedes albopictus.DBD ditandai dengan manifestasi klinis seperti demam mendadak tinggi yang berlangsung terus menerus selama dua samapai tujuh hari, nyeri otot, nyeri sendi, lemah atau lesu, gelisah, nyeri ulu hati, disertai dengan tanda-tanda perdarahan di kulit berupa bintik perdarahan (petechia), ruam (purpura). Kadang-kadang mimisan, berak darah, muntah darah, kesadaran menurun dan dapat menimbulkan renjatan (syok) yang berujung kematian (Candra, 2019).

Penyakit DBD mempunyai tiga fase saat menginfeksi manusia. Fase pertama adalah fase demam dimana penderita akan mengalami panas badan $>38^{\circ} \mathrm{C}$ selama tiga hari berturut-turut. Pada fase kedua yang disebut dengan fase kritis, penderita akan mengalami penurunan suhu $<38^{\circ} \mathrm{C}$ dan umumnya terjadi pada hari keempat dan kelima. Pada fase kedua ini banyak masyarakat beranggapan penyakit sudah sembuh dan memilih tidak memeriksakan diri ke pelayanan kesehatan, akibatnya banyak kasus DBD menjadi fatal dan menyebabkan kematian. Jika penderita DBD dapat melewati fase kritis dengan penanganan yang baik, fase terakhir adalah fase penyembuhan biasanya pada hari keenam dan ketujuh dengan suhu tubuh penderita akan kembali normal. Penyakit DBD mempunyai perjalanan yang cepat sehingga dapat menjadi fatal berujung kematian jika ada keterlambatan penanganan (Candra, 2019).
Pusat Data dan Informasi Kementrian kesehatan RI menunjukkan Angka DBD pada tahun 2017 terdapat 68.407 dengan kasus tertinggi kedua ada di Jawa Timur yaitu sebanyak 7.838. Angka kematian kasus DBD Indonesia di tahun 2017 sebanyak 493 dan angka kematian tertinggi di Jawa Timur sebanyak 105 (Kemenkes RI, 2018). Data dari Dinas Kesehatan Kabupaten Blitar tahun tahun 2016 sebanyak 867 orang, sedangkan penyakit DBD dan SSD sebanyak 308 orang. Angka kematian pada tahun 2016 sebanyak 7 orang. Hasil rekam medik di Puskesmas Kademangan kabupaten Blitar menyatakan penderita yang mengalami penyakit DBD selama tahun 2016 sebanyak 40 orang, angka kematian 1 orang.

Masyarakat sering kali kurang menyadari bahwa demam yang muncul sebagai salah satu gejala penyakit DBD yang dapat berakibat fatal bagi penderita sehingga penderita demam berdarah mengalami keterlambatan penanganan, jatuh pada kondisi syok dengue pada fase kritis akhirnya menyebabkan kematian. Kondisi tersebut disebabkan karena kurangnya pengetahuan masyarakat mengenai gejala demam berdarah dan bahayanya.

Program pemerintah untuk mengatasi DBD selama ini masih hanya menitikberatkan pada upaya pencegahannya saja seperti mengajarkan masyarakat mengidentifikasi jentik nyamuk, program pendidikan kesehatan melalui $3 \mathrm{M}$ plus untuk menghindari jentik nyamuk, termasuk membentuk kader jumantik untuk menggerakkan masyarakat dalam pemberantasan sarang nyamuk (PSN).Tenaga kesehatan atau kader kesehatan di desa jarang mensosialisasikan tentang deteksi dini DBD untuk menghindari terjadinya Sindrom syok Dengue (SSD) kepada masyarakat.

Kader kesehatan di desa sangat dibutuhkan agar dapat berperan menjadi pelopor sekaligus memberikan edukasi kepada masyarakat di lingkungannya sehingga pengetahuan masyarakat tentang DBD dapat ditingkatkan. Pengetahuan masyarakat yang baik tentang DBD akan menjadikan masyarakat mampu melakukan deteksi dini DBD sehingga kondisi fatal yang berakibat kematian pada kasus DBD dapat dicegah. Kader kesehatan dapat menjalankan peran tersebut jika kader kesehatan telah mempunyai pengetahuan yang baik dalam deteksi dini DBD. Namun kenyataanya 
banyak kader kesehatan di desa yang belum mempunyai pengetahuan dan pengetahuan yang cukup dalam deteksi dini DBD disebabkan karena sebagian besar dari tenaga kesehatan khususnya di desa Suruhwadang kecamatan Kademangan kabupaten Blitar hanya mendapat informasi tentang DBD lewat media sosial dan belum pernah mendapatkan pendidikan kesehatan secara intensif dari tenaga kesehatan. Pendidikan kesehatan atau edukasi merupakan upaya terencana untuk mengubah perilaku pada individu maupun kelompok melalui proses perubahan cara berpikir, bersikap, dan berperilaku untuk membantu pengobatan, rehabilitasi, pencegahan penyakit dan promosi kesehatan. Banyak metode edukasi kesehatan yang bisa diterapkan diantaranya metode ceramah dan diskusi, kedua metode tersebut merupakan metode yang tidak mempunyai prosedur yang rumit sehingga sangat mudah dilaksanakan. Penelitian Jatmiko (2018) membuktikan metode ceramah secara efektif dapat meningkatkan pengetahuan masyarakat mengenai penyakit tuberkulosis. Metode diskusi lebih memberikan kesempatan untuk saling mengutarakan pendapat, memecahkan masalah dan membuat kesimpulan sehingga informasi yang ingin disampaikan akan lebih dipahami. Penggabungan metode ceramah dan diskusi diharapkan dapat meningkatkan pengetahuan kader kesehatan dalam deteksi dini DBD.

\section{Metode}

Desain dalam penelitian ini menggunakanquasi experiment dengan rancangan penelitian pretest posttestwithout control group. Populasinya adalah kader kesehatan di desa Suruhwadang kecamatan Kademangan dan besar sampel dalam penelitian ini sebanyak 30 orang yang diambil total populasi. Variabel pengetahuan kader kesehatan diukur dengan menggunakan instrument berupa kuesioner sedangkan metode ceramah dan diskusi diberikan berdasarkan SAP dimana urutan metode edukasi yang dilakukan adalah memberikan materi edukasi terlebih dahulu dengan metode ceramah dilanjutkan dengan dibentuk kelompok diskusi yang masing-masing beranggotakan 6 orang. Masing-masing kelompok diskusi, diberikan pertanyaan dan kasus yang harus dianalisis dan dipecahkan bersama anggota kelompok yang selanjutnya akan dipresentasikan oleh masing-masing kelompok. Analisis data univariat menggunakan distribusi frekuensi jenis kelamin, umur, pekerjaan, dan pendidikan. Analisis bivariat yaitu uji Wilcoxon sign rank test untuk menganalisis perbedaan pengetahuan kader kesehatan antara sebelum dan sesudah dilakukan perlakuan edukasi.

\section{Hasil}

Tabel 1 Tabulasi silang Karakteristik responden dan pengetahuan sebelum edukasi $(\mathbf{n}=30)$

\begin{tabular}{lllllll}
\hline \multirow{2}{*}{$\begin{array}{l}\text { Karakteristi } \\
\text { k }\end{array}$} & \multicolumn{3}{l}{$\begin{array}{l}\text { Pengetahuan } \\
\text { edukasi }\end{array}$} & & \multicolumn{3}{l}{ sebelum } \\
\cline { 2 - 7 } & \multicolumn{3}{l}{ Baik } & \multicolumn{2}{l}{ cukup } & \multicolumn{2}{l}{ Kurang } \\
\cline { 2 - 7 } & f & \% & f & \% & f & \% \\
\hline Usia (tahun) & & & & & & \\
\hline $30-39$ & 9 & 30 & 4 & 13 & 2 & 7 \\
$40-49$ & 6 & 20 & 3 & 10 & 2 & 7 \\
$50-59$ & 1 & 3 & 2 & 7 & 1 & 3 \\
\hline
\end{tabular}

Pendidikan

\begin{tabular}{lllllll}
\hline SD & 1 & 3 & 4 & 13 & 2 & 7 \\
SMP & 4 & 13 & 3 & 10 & 3 & 10 \\
SMA & 11 & 37 & 2 & 7 & 0 & 0 \\
\hline Pekerjaan & & & & & & \\
\hline IRT & 9 & 30 & 4 & 13 & 2 & 7 \\
Swasta & 4 & 13 & 3 & 10 & 2 & 7 \\
Petani & 3 & 10 & 2 & 7 & 1 & 3 \\
\hline Informasi & & & & & & \\
\hline Tidak pernah & 0 & 0 & 7 & 23 & 5 & 17 \\
Pernah & 16 & 53 & 2 & 7 & 0 & 0 \\
\hline
\end{tabular}

Sebelum

dilakukan edukasi, pengetahuan kader kesehatan yang sudah baik didominasi oleh kader pada usia 30-40 tahun sebanyak 9 kader (30\%), berpendidikan terakhir SMA sebanyak 11 kader (37\%), mempunyai pekerjaan sebagai ibu rumah tangga (IRT) sebanyak 9 kader (30\%), dan kader yang pernah mendapat informasi kesehatan yaitu 16 kader (53\%). Sedangkan kader yang masih mempunyai pengetahuan kurang semuanya belum pernah mendapatkan edukasi yaitu sebanyak 5 kader $(17 \%)$ dan juga berpendidikan SD-SMP.

Tabel 2 Tabulasi silang Karakteristik responden dan pengetahuan setelah edukasi $(n=30)$ 


\begin{tabular}{lllll}
\hline \multirow{2}{*}{$\begin{array}{l}\text { Karakteristi } \\
\mathbf{k}\end{array}$} & \multicolumn{4}{l}{ Pengetahuan setelah edukasi } \\
\cline { 2 - 5 } & $\mathbf{B a i k}$ & \multicolumn{3}{c}{ cukup } \\
\cline { 2 - 5 } & $\mathbf{F}$ & $\mathbf{\%}$ & $\mathbf{f}$ & $\mathbf{\%}$ \\
\hline Jenis Kelamin & & & \\
\hline Laki-laki & 4 & 13 & 0 & 0 \\
Perempuan & 21 & 70 & 5 & 17 \\
\hline Pendidikan & & & & \\
\hline SD & 4 & 13 & 3 & 10 \\
SMP & 8 & 27 & 2 & 7 \\
SMA & 13 & 43 & 0 & 0 \\
\hline Usia (tahun) & & & & \\
\hline 30-39 & 12 & 40 & 3 & 10 \\
40-49 & 11 & 36 & 0 & 0 \\
50-59 & 2 & 7 & 2 & 7 \\
\hline Informasi & \multicolumn{4}{l}{} \\
\hline Tidak pernah & 7 & 23 & 5 & 17 \\
Pernah & 18 & 60 & 0 & 0 \\
\hline Keluarga menderita DBD & & \\
\hline Pernah & 22 & 73 & 5 & 17 \\
Tidak pernah & 3 & 10 & 0 & 0 \\
\hline
\end{tabular}

Setelah mendapatkan edukasi, tidak ada kader yang mempunyai pengetahuan kurang. Kader yang berpengetahuan baik didominasi oleh kader perempuan yaitu 21 kader (70 \%), berpendidikan terakhir SMA sebanyak 13 kader (43\%), usia 30-39 tahun sebanyak 12 kader $(40 \%)$ dan usia 40-49 tahun sebanyak 11 kader (36\%). Kader yang berpengetahuan menjadi baik juga didominasi oleh kader yang mempunyai anggota keluarga yang pernah menderita DBD yaitu 22 orang (73\%). Dari 5 kader (17 \%) yang belum pernah mendapatkan informasi tentang DBD, 3 (10\%) kader menjadi berpengetahuan baik setelah diberikan edukasi dan sisanya 2 kader (7\%) menjadi berpengetahuan cukup.

Tabel 3 Pengetahuan kader kesehatan pretest-posttest dalam deteksi dini DBD

\begin{tabular}{lllll}
\hline \multirow{2}{*}{ Pengetahuan } & \multicolumn{2}{l}{ Pretest } & \multicolumn{2}{l}{ posttest } \\
\cline { 2 - 5 } & F & \% & F & \% \\
\hline Baik & 16 & 53 & 25 & 83 \\
Cukup & 9 & 30 & 5 & 17 \\
Kurang & 5 & 17 & 0 & 0 \\
\hline
\end{tabular}

Wilcoxon sign rank test $\mathrm{p}=0,001$

Hasil analisa data menggunakan Wilcoxon sign rank test menunjukkan $\mathrm{p}=0,001$ artinya bahwa terdapat perbedaan pengetahuan yang signifikan antara sebelum dan setelah diberikan edukasi. Sebelum diberikan edukasi 5 kader (17 \%) masih mempunyai pengetahuan yang kurang tetapi setelah diberikan edukasi tidak ada kader yang mempunyai pengetahuan kurang $(0 \%)$.

\section{Pembahasan \\ Dalam penelitian yang sudah dilakukan di desa Suruhwadang kecamatan} Kademangan, didapatkan bahwa pengetahuan responden sebelum diberikan edukasi di desa Suruhwadang kecamatan Kademangan, pengetahuan dalam kategori baik lebih banyak pada rentang usia paling muda yaitu 30-39 tahun sebanyak 9 (30\%) kader kesehatan. Pada masa sekarang ini segala informasi dapat dengan mudah didapatkan melalui media internet, usia 30-39 tahun di masa sekarang menjadi usia dewasa yang masih mampu mengikuti perkembangan teknologi dengan baik terutama internet sehingga pada rentang usia ini kader kesehatan lebih mudah mendapatkan informasi tentang DBD. Hal ini terlihat 16 (53\%) kader yang mempunyai pengetahuan sudah baik ternyata pernah mendapatkan informasi. Menurut Notoatmodjo (2011) informasi yang diperoleh dari berbagai sumber akan mempengaruhi tingkat pengetahuan seseorang. Bila seseorang memperoleh banyak informasi maka ia cenderung mempunyai pengetahuan lebih luas.

Hal lain yang menyebabkan pengetahuan kader sudah baik sebelum diberikan edukasi ini kemungkinan disebabkan karena tingkat pendidikan kader yang rata-rata menyelesaikan pendidikan akhir SMA, adapun responden dengan pengetahuan baik pendidikan terakhir SMA sebanyak 11 kader. Pendidikan dapat membentuk pola hidup terutama perilaku seseorang dalam motivasi untuk mendapatkan informasi. Pada umumnya makin tinggi pendidikan seseorang, makin mudah menerima informasi (Notoatmodjo, 2011).

Sebanyak 9 kader yang mempunyai pengetahuan kategori baik bekerja sebagai ibu rumah tangga. Ibu rumah tangga merupakan pekerjaan yang tidak terlalu menyita waktu dan lebih mempunyai waktu luang dan kesempatan yang fleksibel untuk mencari informasi yang dengan mudah didapatkan melalui media online.

Setelah mendapatkan edukasi dengan metode ceramah dan diskusi menunjukkan 
adanya peningkatan jumlah kader berpengetahuan baik lebih banyak pada rentang usia 30-39 tahun dibandingkan rentang usia yang lebih tua terutama pada usia 50-59 tahun. Kader usia 30-39 tahun dengan pengetahuan baik meningkat menjadi 12 orang sesudah diberikan edukasi, sehingga dapat disimpulkan responden pada rentang usia tersebut mampu memahami, menjelaskan serta menyimpulkan materi yang di berikan. Memahami diartikan sebagai suatu pengetahuan menjelaskan secara benar tentang objek yang diketahui, dan dapat menginterpretasi materi tersebut secara benar (Notoatmodjo, 2011).

Kader yang pernah memperoleh informasi tentang DBD baik melalui media cetak, elektronik, internet maupun tenaga kesehatan maupun yang belum pernah mendapat informasi mengalami peningkatan pengetahuan deteksi dini DBD setelah diberikan edukasi. Demikian juga pada semua jenjang pendidikan terakhir mengalami peningkatan pengetahuan yang hampir sama sehingga menunjukkan apapun tingkat pendidikan terakhir kader dan informasi yang pernah diterima, dengan metode ceramah yang dipadukan dengan diskusi tetap dapat meningkatkan pengetahuan kader karena meskipun secara konsep orang dengan pendidikan lebih tinggi atau pernah mendapatkan informasi lebih mudah menyerap informasi kembali, namun dengan memberikan metode diskusi pemahaman yang mungkin belum didapatkan oleh beberapa kader saat diberikan edukasi dengan ceramah dapat diperdalam dengan metode diskusi. Dalam metode diskusi, kader yang telah mendapatkan pemahaman yang baik dapat membantu kader lain yang belum paham, hal inilah yang menyebabkan pada semua jenjang pendidikan terjadi peningkatan pengetahuan kader dengan presentase yang hampir sama.

Analisis wilcoxon sign rank test (tabel 3) menunjukkan perbedaan yang signifikan antara sebelum diberikan edukasi dan sesudah diberikan edukasi terhadap pengetahuan kader kesehatan dalam mendeteksi dini DHF di desa Suruhwadang kecamatan Kademangan kabupaten Blitar $(\mathrm{p}=0,001)$. Kader dengan kategori pengetahuan baik sebelum diberikan edukasi sebanyak $53 \%$, setelah diberikan edukasi menjadi $83 \%$ dan tidak ada lagi kader yang memiliki pengetahuan kurang dimana sebelumnya ada $17 \%$ kader yang pengetahuannya masih kurang.

Pengetahuan deteksi dini DBD dalam penelitian ini meliputi pengetahuan dalam memahami pengertian, mengenali tanda gejala, penyebab, penatalaksanaan, pencegahan, siklus/fase DBD dan juga tanda sindrom syok dengue (SSD). Edukasi diberikan dengan metode ceramah yaitu memberikan materi tentang DBD menggunakan media powerpoint dan leaflet. Selanjutnya eduksi diteruskan dengan metode diskusi yaitu membagi peserta edukasi menjadi kelompok-kelompok kecil terdiri dari 6 anggota kelompok. Masing-masing kelompok diberikan pertanyaan seputar materi yang telah disampaikan, kasus deteksi dini DBD yang harus dipecahkan bersama oleh semua anggota kelompok.

Bagian akhir dari edukasi ini adalah berupa presentasi hasil penugasan oleh perwakilan masing-masing kelompok. Dalam presentasi ini dilakukan diskusi kembali membahas hasil pengerjaan tugas masingmasing kelompok yang melibatkan seluruh peserta edukasi. Serangkaian metode edukasi tersebut telah terbukti dapat meningkatkan pengetahuan kader kesehatan dalam deteksi dini DBD yang diukur dengan kuesioner saat post test oleh masing-masing individu peserta edukasi.

Metode ceramah maupun diskusi secara berdiri sendiri atau terpisah sebenarnya masing-masing telah terbuti efektif sebagai metode untuk penyuluhan atau pendidikan kesehatan. Seperti dalam penelitian Sakiyah (2015) menunjukkan bahwa baik metode ceramah ataupun diskusi dapat meningkatkan pengetahuan tentang alat pelindung diri (APD) pekerja di bengkel las dan antara kedua metode tersebut tidak ada perbedaan efektifitasnya. Perpaduan metode edukasi ceramah dan diskusi dapat menjadi metode yang tepat untuk meningkatkan pengetahuan kader kesehatan dalam deteksi dini DBD karena di dalam metode tersebut peserta edukasi tidak hanya pasif mendengarkan educator tetapi menjadi lebih aktif untuk menyampaikan pendapat, membuat edukasi tidak hanya pasif mendengarkan educator tetapi menjadi lebih aktif untuk menyampaikan pendapat, membuat kesimpulan atau memecahkan masalah sesuai materi yang dipelajari. Sesuai hasil penelitian Kurniawan (2017) menyimpulkan bahwa 
metode ceramah dan diskusi pada pelatihan kader kesehatan mampu meningkatkan pengetahuan tentang promosi kesehatan ibu dan anak.

\section{Kesimpulan}

Pemberian edukasi dengan menggunakan metode ceramah dan diskusi dapat meningkatkan pengetahuan kader kesehatan dalam deteksi dini DBD dengan nilai signifikansi $\mathrm{p}=0,001$. Pengetahuan kader kesehatan meliputi memahami pengertian, mengenali tanda gejala, penyebab, penatalaksanaan, pencegahan, siklus/fase DBD dan juga tanda sindrom syok dengue (SSD).

\section{Saran}

Diharapkan petugas kesehatan puskesmas dapat meningkatkan peran dan pengetahuan kader kesehatan di setiap desa dalam rangka tercapainya keberhasilan program yang berkaitan dengan DBD yang tidak hanya fokus pada pencegahan dan pengawasan sarang nyamuk tetapi juga deteksi dini DBD sehingga kader kesehatan tidak hanya berperan sebagai jumantik tetapi juga sebagai pelopor deteksi dini DBD untuk mencegah akibat fatal dari penyakit ini.

\section{Ucapan Terima Kasih}

Ucapan terimakasih disampaikan kepada perangkat desa Suruhwadang, puskesmas Kademangan dan dinas kesehatan kabupaten Blitar yang telah membantu atau memberikan ijin untuk melakukan penelitian ini.

\section{Daftar Pustaka}

Candra, A 2019, 'Asupan Gizi dan Penyakit Demam Berdarah/ Dengue Hemoragic Fever (DHF)', Jurnal of Nutrition and Health, vol. 7, no. 2, hh. 23-31

Jatmiko, SW, Romanda, F \&Hidayatulloh, MAA 2018, 'Pengaruh penyuluhan metode ceramah dalam meningkatkan pengetahuan masyarakat terhadap penyakit tuberculosis', Jurnal Litbang Sukowati, vol. 2, no. 1, hh. 17.

Kemenkes RI 2017, InfoDatin: Situasi Penyakit Demam berdaeah tahun 2017. Kemenkes RI, Jakarta.

Kurniawan, S, Gamelia, E \& Sistiarani, C 2017, ‘ Efektivitas pelatihan metode ceramah dan diskusi kader kesehatan untuk emningkatkanpengetahuan tentang kesehatan ibu dan anak di puskesmas I Baturraden',
Jurnal Kesmas Indonesia, vol 9, no, 1, hh.2333

Notoatmodjo 2011, Kesehatan Masyarakat: Ilmu dan Seni, Rineka Cipta, Jakarta.

Sakiyah, M, Jaji \&Muharyati, PW 2015, 'Perbedaan efektifitas metode diskusi dan ceramah terhadap pengetahuan pekerja tentang alat pelindung diri (APD) di bengkel las kelurahan Bukit Tinggi Lama Palemban', Jurnal keperawatan Sriwijaya, vol. 2, no. 2, hh. 115-123.

Wowor, MF 2011, 'Deteksi Dini Demam Berdarah Dengue dengan Pemeriksaan Antigen NS1', Jurnal Biomedik, vol. 3, no. 1, hh. 1-9 